\title{
BIAYA TRANSAKSI DAN PERIODE PEMEGANGAN SAHAM BIASA YANG TERDAFTAR DI BURSA EFEK JAKARTA PERIODE 2002-2004
}

\author{
Agus Zainul Arifin \\ Fakultas Ekonomi, Universitas Tarumanegara Jakarta \\ e-mail:a_z_arifin@yahoo.com \\ Tan Grace Tanzil \\ Fakultas Ekonomi, Universitas Tarumanegara Jakarta \\ e-mail: grace_keai@yahoo.com
}

\begin{abstract}
The purpose of this research is to investigate the influence of transaction costs for the period of shareholding. This research is a replication of the Atkins and Dyl (1997). The first part of the invested transaction cost which represented the bid-ask spread on the holding period. On the Atkins and Dyl (1997) research had added the control variables as independent variables in the form of market value and variance of stock returns. This research employs 30 companies has been taken as sample deemed all of the criteria on period 2002-2004. Analysis of the hypothesis was taken using $2 S L S$ (two stage least square) regression. The result of this research indicate that the bid-ask spread, market value, and variance of stock return have a significant influence on the holding period of shares registered in Jakarta Stock Exchange.
\end{abstract}

Keywords: transaction cost, bid-ask spread, holding period, market value, variance of stock return

\section{PENDAHULUAN}

Tujuan investasi adalah untuk mendapatkan manfaat berupa return investasi. Investasi terbagi dua yaitu investasi jangka pendek dan investasi jangka panjang. Pada investasi jangka pendek investor bertujuan untuk mengambil keuntungan dari perubahan harga saja. Sedangkan pada investasi jangka panjang selain bertujuan mengambil keuntungan dari perubahan harga, juga untuk memperoleh keuntungan (gain).

Investor jangka pendek akan menjual saham yang dimilikinya ketika melihat perubahan harga yang menguntungkan. Adanya bid-ask spread yang merupakan perbedaan antara harga order jual terendah (ask price) dan harga order beli tertinggi (bid price) (Brockman dan Chung, 1999) adalah bagian dari variabel transaction cost, akan mengurangi keuntungan investor. Makin besar bid-ask spread, akan semakin lama investor menyimpan investasinya (holding period), dan sebaliknya, karena investor harus menunggu perubahan harga yang lebih besar dari pada biaya transaksinya, ditambah dengan keuntungan yang diharapkan oleh investor, sebelum dia menjual sahamnya (Sharpe, Alexander, dan Bailey, 1999).

Fakta yang terjadi, ada juga saham yang mempunyai bid-ask spread kecil tetapi holding period-nya lama (Tabel 1.) dan juga sebaliknya (Tabel 2.). 
Jurnal Siasat Bisnis Vol. 12 No. 3, Desember 2008 Hal: 161-173

Tabel 1: Saham yang Memiliki Persentase Bid-Ask Spread Kecil dengan Holding Period Lama pada Tahun 2002

\begin{tabular}{lcc}
\hline \multicolumn{1}{c}{ Nama Perusahaan } & Bid-Ask Spread & Holding Period \\
\hline Aqua Golden Mississippi Tbk. & $12.26 \%$ & 221.22 hari \\
Multi Bintang Indonesia Tbk. & $14.44 \%$ & 124.67 hari \\
Citra Tubindo Tbk. & $9.45 \%$ & 373.83 hari \\
Goodyear Indonesia Tbk. & $8.31 \%$ & 144.37 hari \\
\hline
\end{tabular}

Sumber : Data sekunder diolah dari Pusat Referensi Pasar Modal (lampiran 3)

Tabel 2: Saham yang Memiliki Persentase Bid-Ask Spread Besar dengan Holding Period Singkat pada Tahun 2002

\begin{tabular}{lcc}
\hline \multicolumn{1}{c}{ Nama Perusahaan } & Bid-Ask Spread & Holding Period \\
\hline Bakrie \& Brothers Tbk. & $30.37 \%$ & 10.95 hari \\
Siwani Trimitra Tbk. & $16.60 \%$ & 5.155 hari \\
Asiaplast Industries Tbk. & $15.38 \%$ & 0.019 hari \\
Wahana Phonix Mandiri Tbk. & $15.15 \%$ & 8.944 hari \\
\hline
\end{tabular}

Sumber: Data sekunder diolah dari Pusat Referensi Pasar Modal (lampiran 3)

Fakta yang terjadi, ada juga investor asing yang menginvestasikan dananya pada saham yang market valuenya tinggi. Tapi ada pula saham yang menginvestasikan pada saham yang mempunyai market value rendah. Demikian pula untuk investor non asing yang menginvestasikan dananya pada saham yang mempunyai market value rendah atau tinggi.

Berdasarkan teori dan fenomena yang telah diuraikan, maka perlu diteliti kembali pengaruh transaction cost, market value, varians of stock return terhadap holding period. Fokus penelitian ini dilakukan terhadap saham biasa yang terdaftar di Bursa Efek Jakarta dengan tujuan untuk mengetahui bagaimana hubungan antara biaya transaksi dengan periode pemegangan saham biasa yang Terdaftar di Bursa Efek Jakarta Periode 2002-2004. Pada penelitian ini ditambah variabel kontrol sebagai variabel independen berupa market value dan variance of stock return. Penentuan variabel kontrol ini sesuai dengan yang telah diteliti oleh Atkins dan Dyl (1997).

Berdasarkan latar belakang yang telah diuraikan, maka tujuan penelitian ini adalah: a). Mengetahui pengaruh bid-ask spread terhadap holding period. b).
Mengetahui pengaruh market value terhadap holding period; c). Mengetahui pengaruh variance of stock return terhadap holding period; d). Mengetahui pengaruh bid-ask spread, market value, dan variance of stock return terhadap holding period.

\section{KAJIAN PUSTAKA}

Brockman dan Chung (1999) membagi sistem pasar modal menjadi dua, yaitu Hybrid quote-driven system dan Orderdriven system. Dalam sistem yang pertama, market maker yang telah ditunjuk menyediakan likuiditas di pasar modal dengan secara terus-menerus memberikan bid price dan ask price untuk sekuritas-sekuritas yang mau diperdagangkannya. Investor yang memerlukan likuiditas tunduk terhadap market order yang disesuaikan dengan bid price dan ask price yang diberikan oleh market maker. Adapun dalam sistem Orderdriven para investor membatasi order yang menyebabkan timbulnya likuiditas di pasar modal dan membentuk bid-ask spread. Bursa Efek Jakarta menganut sistem ini.

\section{Bid - ask Spread}

Bid price adalah harga tertinggi yang dirtawarkan investor yang akan membeli 
suatu saham, sedangkan ask price adalah harga terendah yang ditawarkan investor yang akan menjual suatu saham. Bid-ask spread yang terlalu tinggi akan menguntungkan bagi pialang/dealer, namun bidask spread yang terlalu tinggi akan menyebabkan saham tersebut menjadi kurang aktif diperdagangkan. Bid-ask spread yang terlalu rendah akan merugikan bagi pialang/dealer, namun bid-ask spread yang terlalu rendah akan menyebabkan saham tersebut menjadi lebih aktif diperdagangkan. Oleh karena itu, pialang/dealer akan berusaha untuk menentukan tingkat bid-ask spread yang optimal, yaitu tingkat bid-ask spread yang tidak merugikan pialang/dealer dan membuat saham tersebut aktif diperdagangkan. Menurut Jones (2002), spread merupakan selisih antara harga beli (bid) tertinggi yang menyebabkan investor bersedia untuk membeli saham tertentu dengan harga jual (ask) terendah yang menyebabkan investor bersedia untuk menjual sahamnya.

\section{Model spread}

Fatmawati dan Asri (1999), menjelaksan bahwa spread mempunyai dua model yaitu: 1). Dealer spread adalah selisih antara harga bid dan harga ask yang menyebabkan dealer ingin memperdagangkan sekuritas dengan aktivanya sendiri untuk mendapatkan keuntungan sendiri; 2). Market spread merupakan perbedaan antara highest bid dengan lower ask yang terjadi pada suatu saat tertentu.

Spread tidak terlepas dari aktivitas yang dilakukan oleh pihak-pihak tertentu yang dapat mempengaharui besarnya transaksi sekuritas di lantai bursa, salah satunya adalah Pedagang Perantara Efek (PPE) yang berfungsi sebagai dealer, penasehat investasi dan broker. Dengan diterapkannya Order Driven Market System pada pasar modal Indonesia, yang berarti bahwa investor hanya dapat melakukan transaksi melalui jasa broker, maka penelitian ini menggunakan market spread dengan alasan bahwa dealer spread tidak dapat diamati (unobservable) di Bursa Efek Jakarta (BEJ).

\section{Formulasi bid-ask spread}

Pengukuran bid-ask spread berdasarkan penelitian yang dilakukan Atkins dan Dyl (1997) menggunakan persamaan (1):

Spread $i \mathrm{~T}=\left[\sum_{\mathrm{t}=1}^{\mathrm{N}} \frac{\mathrm{Ask}_{\mathrm{it}}-\mathrm{Bid}_{\mathrm{it}}}{\left(\text { Ask }_{\mathrm{it}}+\mathrm{Bid}_{\mathrm{it}}\right) / 2}\right] / \mathrm{N}$

Sumber : Atkins dan Dyl (1997:317)

Keterangan :

Spread $_{\mathrm{i}, \mathrm{T}}$ : rata-rata bid-ask spread dari saham i pada tahun $\mathrm{T}$

Ask $_{\mathrm{i}, \mathrm{T}}$ : harga penawaran terendah yang menyebabkan investor setuju untuk menjual saham i pada hari t selama tahun $\mathrm{T}$

Bid i,T : harga penawaran tertinggi yang menyebabkan investor setuju untuk membeli saham i pada hari t selama tahun $\mathrm{T}$

$\mathrm{N} \quad$ : total jumlah hari perdagangan saham i selama tahun $\mathrm{T}$

\section{Harga pasar saham (market value)}

Widoatmodjo (1996) menjelaskan bahwa harga pasar terjadi setelah saham tersebut dicatatkan di bursa, baik bursa utama maupun OTC (Over the Counter). Tinggi rendahnya harga pasar saham ini tergantung pada kekuatan tawar-menawar di pasar sekunder. Husnan (1998) menyebutkan pembentukan harga di BEJ dikelompokkan menjadi dua tipe, yaitu pasar lelang dan pasar negosiasi. Pada perdagangan regular, harga terbentuk sesuai dengan harga lelang, dengan proses tawar menawar didasarkan atas prioritas harga dan prioritas waktu. Dengan sistem ini maka para pialang akan memasukan order yang mereka terima dari pemodal (atau order atas nama mereka sendiri) ke dalam terminal komputer mereka 
di lantai bursa. Apabila permintaan akan suatu saham besar, sementara penawaran sedikit, maka harga saham akan naik. Sebaliknya, Karena itu sistem yang dipergunakan oleh BEJ disebut juga sebagai order driven market.

Widoatmodjo (1996) menjelaskan bahwa faktor utama yang menyebabkan harga pasar saham berubah adalah adanya persepsi yang berbeda-beda dari masingmasing investor, sesuai dengan informasi yang dimiliki. Persepsi tersebut dicerminkan melalui Rate of Return (ROR). Apabila sebagian besar investor suatu saham mempunyai persepsi bahwa ROR saham tersebut tidak memadai lagi, maka mereka akan mengambil keputusan untuk menjualnya. Jika ini yang terjadi, maka harga saham akan menurun. Sebab, kemungkinan akan terjadi over supply. Demikian jika sebaliknya, Market value dapat dihitung dengan persamaan (2):

Mkt $\quad \mathrm{Val}_{\mathrm{iT}}=\ln \left(\left[\sum_{\mathrm{t}=1}^{\mathrm{N}} \mathrm{Pt} / \mathrm{N}\right] \mathrm{X} \begin{array}{c}\text { Jumlah sahami } \\ \text { yang beredar } \\ \text { per akhir } \\ \text { tahun } \mathrm{T}\end{array}\right)$.

Sumber : Atkins dan Dyl (1997:316)

Keterangan:

$\mathrm{Mkt} \mathrm{Val}_{\mathrm{iT}}$ : rata-rata harga saham i yang terjadi di bursa dalam tahun $\mathrm{T}$ (market value)

Ln : logaritma natural

Pt : harga penutupan saham i di Bursa efek pada hari $t$ dalam tahun $\mathrm{T}$

$\mathrm{N}$ : total jumlah hari perdagangan untuk saham i di bursa efek dalam tahun $\mathrm{T}$

1 : saham badan usaha $\mathrm{i}$

$\mathrm{t}$ : hari perdagangan saham dalam tahun $\mathrm{T}$

$\mathrm{T}$ : tahun penelitian

Market value dapat digunakan untuk mengukur skala badan usaha. Dalam melakukan investasi di pasar modal, investor cenderung memilih saham badan usaha besar daripada saham badan usaha kecil.
Saham badan usaha besar mungkin mengurangi perbedaaan harapan investor, yang meneyebabkan perdagangan sahamnya lebih sedikit, dan oleh karena itu holding period-nya lebih lama. Saham badan usaha besar mempunyai stabilitas yang lebih baik dalam parameter distribusi return-nya. Saham yang distribusi return-nya stabil cenderung dipegang investor lebih lama, sehingga holding period menjadi lebih lama. Pada dasarnya market value berpengaruh terhadap holding period (Alfons dan Endang, 2003).

\section{Variance of the stock return}

Besarnya variance ditentukan oleh pergerakan harga saham di pasar. Pergerakan harga yang fluktuatif akan menghasilkan variasi yang besar juga. Variance yang besar akan membuat investor memiliki peluang yang besar untuk mendapatkan keuntungan yang besar juga dari adanya perubahan harga, dan juga sebaliknya (Tjiptono dan Hendy, 2001:10).

Variance of stock return adalah pengukuran besarnya resiko total yang dikaitkan dengan expexted return dari suatu investasi saham badan usaha $\mathrm{i}$ dalam tahun $\mathrm{T}$ selama periode tertentu yang dinyatakan dalam satuan (\%). Variance of stock return dapat dihitung dengan persamaan (3), (4) dan (5) (Atkins dan Dyl, 1997).

$$
\begin{aligned}
& \operatorname{Var} \operatorname{Re} \mathrm{t}_{\mathrm{iT}}=\ln \left(\sum_{\mathrm{t}=1}^{\mathrm{N}}\left[\mathrm{HPY}_{\mathrm{it}}-\mathrm{E}\left(\mathrm{HPY} \mathrm{iT}_{\mathrm{T}}\right)\right]^{2}\right) / \mathrm{N} \\
& \mathrm{HPY}_{\mathrm{it}}=\frac{\mathrm{P}_{\mathrm{t}}-\mathrm{P}_{\mathrm{t}-1}}{\mathrm{P}_{\mathrm{t}-1}} \\
& \mathrm{E}\left(\mathrm{HPY}_{\mathrm{iT}}\right)=\sum_{\mathrm{t}=1}^{\mathrm{N}} \mathrm{HPY}_{\mathrm{iT}} / \mathrm{N}
\end{aligned}
$$

Sumber : Atkins dan Dyl (1997:316)

Keterangan:

VarRet $_{\mathrm{iT}}$ : variance of stock return saham i yang terjadi di bursa dalam tahun $\mathrm{T}$ 
$\mathrm{HPY}_{\mathrm{iT}}$ : holding period yield saham i di bursa efek dalam tahun $\mathrm{T}$

$\mathrm{E}\left(\mathrm{HPY}_{\mathrm{iT}}\right)$ : expected value of holding period yield saham i dalam tahun $\mathrm{T}$

Ln : logaritma natural

$\mathrm{N}$ : total jumlah hari perdagangan untuk saham i di bursa efek dalam tahun $\mathrm{T}$

I : saham badan usaha $\mathrm{i}$

$\mathrm{t}$ : hari perdagangan saham dalam tahun $\mathrm{T}$

$\mathrm{T} \quad$ : tahun penelitian

$\mathrm{HPY}_{\mathrm{iT}}$ : holding period yield saham badan usaha i di bursa efek pada haridalam tahun $\mathrm{T}$ selama periode tertentu.

$\mathrm{P}_{\mathrm{t}}$ : harga penutupan saham badan usaha $\mathrm{i}$ di bursa efek pada hari $\mathrm{t}$ dalam tahun $\mathrm{T}$ selama periode tertentu.

$\mathrm{P}_{\mathrm{t}-1}$ : harga penutupan saham badan usaha i di bursa efek pada hari t-1 dalam tahun $\mathrm{T}$ selama periode tertentu.

Seorang investor yang pencari resiko (risk seeker) maka ia akan cenderung menginvestasikan dananya pada saham yang mempunyai variance yang besar. Setelah ia memperoleh keuntungan dari adanya perubahan harga maka ia akan menjual saham tersebut. Jadi pada dasarnya hubungan antara variance of stock return dengan holding period adalah negatif (Atkins dan Dyl, 1997).

\section{Holding period}

Holding period adalah proksi untuk transaction cost. Transaction cost pada dasarnya merupakan selisih harga jual dan beli saat periode yang bersamaan. Jika seseorang memiliki target return terhadap investasinya maka ia harus menyimpan investasinya tersebut lebih lama, dikarenakan ia harus menunggu kenaikan harga sebesar transaction cost ditambah lagi dengan return yang diharapkan oleh si investor. Jadi, dapat disimpulkan bahwa perubahan holding period akan sebanding dengan jangka waktu perubahan harga sebanyak transation cost. Semakin besar transaction cost maka akan semakin lama holding periodnya (Atkins dan Dyl,1997).

Menurut Atkins and Dyl (1997) holding period merupakan variabel yang memberikan indikasi tentang rata-rata panjangnya waktu investor untuk menahan saham suatu perusahaan. Holding period dapat dihitung dengan menggunakan persamaan (6).

$$
\begin{gathered}
\text { Holding }_{\text {Periode }} \mathrm{iT} \\
\text { Peredar tiap akhir tahun T }^{\text {i dalam tahun T }}
\end{gathered}
$$

\section{Penelitian yang Relevan}

Atkins dan Dyl (1997) melakukan penelitian yang mencakup tiga bagian yaitu: a). Bagian pertama meneliti pengaruh transaction cost yang diwakili oleh bid-ask spread, market value, dan variance of stock return terhadap lamanya investor memegang saham (holding period); b). Bagian kedua meneliti pengaruh antara perubahan holding period dan perubahan bid-ask spread; c). Bagian ketiga meneliti permasalahan arah kausalitas (Granger causality) antara holding period dan bid-ask spread.

Data penelitian yang dilakukan di New York Stock Exchange (NYSE) dan NASDAQ periode 1975-1991 dengan jumlah sampel 32.000. Hasil penelitian menyimpulkan bahwa lamanya investor memegang saham biasa (holding period) dipengaruhi oleh bid-ask spread, market value, dan variance of stock return. Kesimpulan lain yang didapat adalah panjangnya holding period investor berhubungan positif dengan bid-ask spread, yang dibuktikan dengan ditemukannya hubungan yang lebih kuat antara kedua variabel tersebut di 
NASDAQ yang mempunyai spread yang lebih besar daripada di NYSE terhadap lamanya holding period.

Lenny dan Nur Indrianto (1999) melakukan penelitian tentang pengaruh transaction cost terhadap lamanya holding period saham biasa periode 1995-1996." Hasil penelitian ini dapat disimpulkan bahwa lamanya kepemilikan suatu saham biasa di Bursa Efek Jakarta dipengaruhi oleh faktor-faktor bid-ask spread, market value, dan variance return, dan menemukan bahwa market value merupakan faktor yang paling berpengaruh terhadap lamanya kepemilikan suatu saham, yang berarti semakin besar nilai perusahaan, investor-investor di Bursa Efek Jakarta akan semakin lama menahan kepemilikan sahamnya. Terdapat bukti bahwa secara parsial bid-ask spread berpengaruh positif namun tidak signifikan terhadap lamaya investor menahan suatu saham. Sedangkan secara simultan membuktikan bahwa variabel bid-ask spread, market value, dan variance return dapat menjelaskan lamanya kepemilikan suatu saham biasa.

Subali dan Zuhroh (2002) meneliti pengaruh transaction cost terhadap holding period saham biasa tahun 2000. Hasil penelitian ini menyimpulkan bahwa lamanya kepemilikan suatu saham biasa di Bursa Efek Jakarta dipengaruhi oleh faktor-faktor bid-ask spread, market value, dan risk of return. Secara parsial ditemukan bahwa hanya variabel market value saja yang berpengaruh signifikan terhadap holding period untuk semester satu dan dua pada level 5\%. Sedangkan variabel bid-ask spread berpengaruh signifikan pada semester satu tepatnya pada level $(0,0793)$ dan signifikan pada semester dua. Secara simultan menunjukkan bahwa semua variabel bebas mempengaruhi variabel terikat secara signifikan hanya pada semester satu pada level 5\%, sedangkan pada semester dua baru signifikan pada level $10 \%$.
Miapuspita, dkk (2003) meneliti pengaruh bid-ask spread, market value, dan risk of return Saham terhadap holding period pada saham teraktif yang tercatat di bursa efek Jakarta periode 2001-2002. Hasil penelitian ini menyimpulkan bahwa holding period dipengaruhi oleh variabel-variabel bid-ask spread, market value, dan risk of return. Secara simultan menunjukkan bahwa semua variabel bebas mempunyai pengaruh signifikan terhadap variabel terikat sebesar $13,5 \%$. Sedangkan secara parsial ditunjukkan bahwa variabel bid-ask spread mempunyai pengaruh negatif signifikan, market value mempunyai pengaruh positif signifikan, dan risk of return mempunyai pengaruh negatif namun tidak signifikan terhadap holding period.

Puspita (2005) meneliti pengaruh bid-ask spread, market value, dan risk of return stock terhadap holding period saham biasa. Hasil penelitian dapat disimpulkan secara simultan bid-ask spread, market value dan risk of return saham memeiliki pengaruh signifikan terhadap holding period saham pada level 5\%. Sedangkan secara parsial menunjukkan bahwa variabel bid-ask spread memiliki pengaruh dengan arah negatif, untuk variabel market value memiliki pengaruh positif dan variabel risk of return memiliki arah hubungan yang positif namun tidak berpengaruh signifikan terhadap holding period saham.

\section{Kerangka Pemikiran}

Dari kajian teori dan pemikiran yang relevan, maka kerangka pemikiran dalam penelitian ini digambarkan pada Gambar 1. Kerangka pemikiran ini adalah replikasi ulang dari penelitian yang dilakukan oleh Atkins dan Dyl (1997) yang diteliti kembali di Bursa Efek Jakarta periode tahun 2002 2004. 
$\mathrm{H} 4$

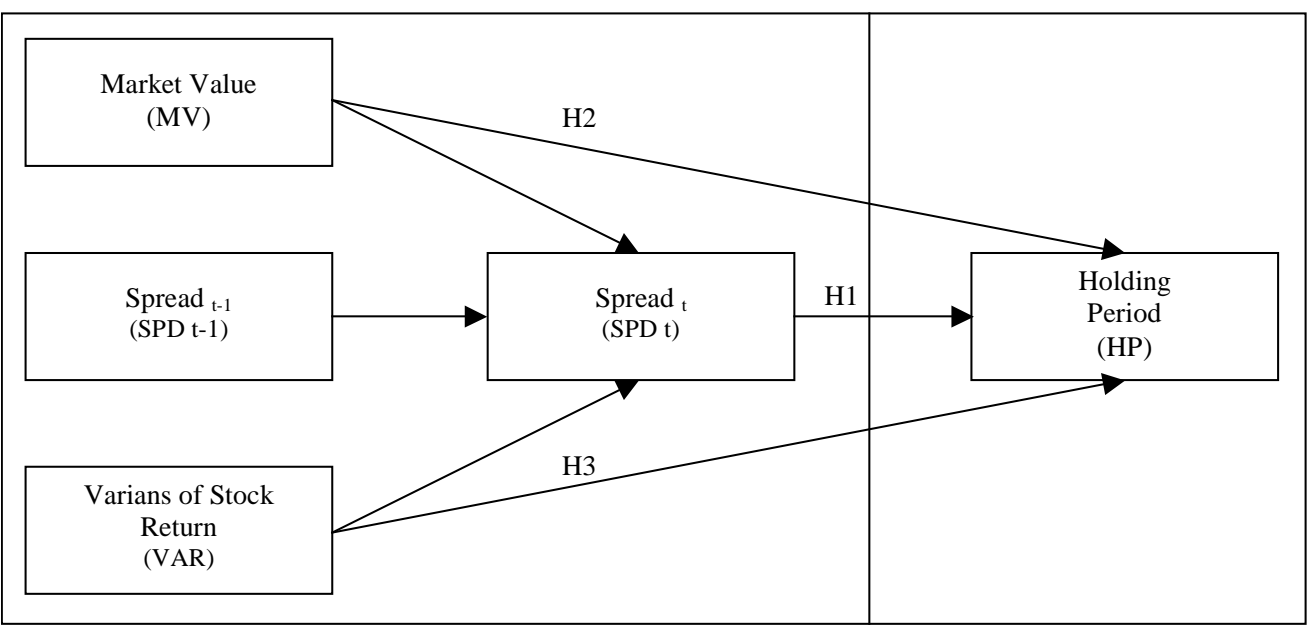

Gambar 1: Kerangka Pemikiran

\section{Hipotesis}

Berdasarkan kajian teori dan kerangka pemikiran maka hipotesis yang dibangun adalah, a). Bid-ask spread berpengaruh positif terhadap holding period; 2). Market value berpengaruh positif terhadap holding period; 3). Variance of stock return berpengaruh negatif terhadap holding period; 4). Bid-ask spread, market value, variance of stock return berpengaruh terhadap holding period.

\section{METODE PENELITIAN}

Subyek penelitian ini adalah seluruh perusahaan yang terdaftar di Bursa Efek Jakarta yang tidak pernah mengalami corporate action selama periode 2002-2004. Objek penelitian ini secara umum mencakup analisis yang didasarkan pada transaction cost yang diwakili oleh Prediksi bid-ask spread, market value, variance of stock return sebagai variabel eksogen, dan holding period saham. Bid-ask spread, market value dan variance of stock return adalah variabel eksogen sedangkan variabel holding period sebagai variabel endogen.

Penelitian ini dirancang sebagai penelitian deskriptif dan verifikatif melalui pendekatan kuantitatif yang bertujuan untuk menyajikan gambaran secara terstruktur, faktual dan akurat mengenai fakta-fakta, sifat serta hubungan antar variabel yang diteliti (Nazir, 1999). Tujuan penelitian adalah untuk membuktikan apakah bid-ask spread sekuritas yang lebih tinggi menyebabkan investor berharap memegang sekuritas yang dimilikinya dalam jangka waktu yang lebih lama, demikian sebaliknya. Juga untuk mengetahui apakah makin lama holding period berhubungan dengan makin besarnya badan usaha yang diukur dengan market value, serta makin singkat holding period berhubungan dengan makin volatilnya badan usaha yang diukur dengan variance of stock return.

Teknik sampling yang digunakan adalah metode porposive sampling dengan kriteria tidak pernah melakukan corporate action dan dipilih 30 perusahaan yang mewakili 9 sektor yang ada selama periode 2002-2004. Data yang digunakan adalah data sekunder yang tercatat dalam Pusat Data Pasar Modal UGM dan JSX Statistics pada periode penelitian di Bursa Efek Jakarta. Sedangkan analisis data yang digunakan adalah analisis regresi berganda. 
Beberapa alasan yang dipertimbangkan dalam pengambilan periode penelitian ini adalah, a). Kenaikan volume perdagangan saham yaitu dari 171.207.351.815 saham di tahun 2002 menjadi 411.768.340.217 saham di tahun 2004; b). Kenaikan nilai saham yaitu dari Rp120.762.778.011.033,- di tahun 2002 menjadi Rp 247.006.931.714.305,- di tahun 2004. c). Kenaikan frekuensi perdagangan saham yaitu dari 3.092.206 kali di tahun 2002 menjadi 3.723.950 kali di tahun 2004. d). Pada tahun 2002 adalah puncak bagi Indonesia yang memiliki perbandingan investor asing paling sedikit yaitu $8 \%$, dengan $92 \%$ lainnya investor domestik untuk perdagangan sahamnya.

\section{Operasionalisasi Variabel}

Berdasarkan kajian teori, kerangka pemikiran dan hipotesis yang diajukan, variabel yang digunakan dalam penelitian ini diringkas pada Tabel 3:

Tabel 3: Operasionalisasi Variabel

\begin{tabular}{|c|c|c|c|}
\hline Variabel & Konsep Variabel & Rumus & Skala \\
\hline $\begin{array}{c}\text { Holding period } \\
\text { (Var. Endogen) }\end{array}$ & $\begin{array}{l}\text { Periode waktu dimana seorang } \\
\text { investor dianggap menginvestasikan } \\
\text { sejumlah uang tertentu (Sharpe, } \\
\text { Alexander, dan Bailey, 1999: Reilly } \\
\text { dan Brown, 2000) }\end{array}$ & $\begin{array}{l}\text { Membagi jumlah saham yang } \\
\text { beredar per akhir tahun } T \text { dengan } \\
\text { jumlah volume perdagangan saham } \\
\text { harian dalam satu tahun (Persamaan } \\
\text { 6) }\end{array}$ & Rasio \\
\hline $\begin{array}{l}\text { Bid-ask spread } \\
\text { (Var. Eksogen) }\end{array}$ & $\begin{array}{l}\text { Perbedaan harga order jual terendah } \\
\text { (ask price) dan harga order beli } \\
\text { tertinggi (bid price) untuk saham } \\
\text { badan usaha (Brockman dan Chung, } \\
\text { 1999: 227) }\end{array}$ & $\begin{array}{l}\text { Merata-ratakan bid-ask spread } \\
\text { harian. Bid-ask spread harian } \\
\text { merupakan selisih ask price dan bid } \\
\text { price harian dengan rata-rata jumlah } \\
\text { ask price dan bid price harian. } \\
\text { (Persamaan 1) }\end{array}$ & Rasio \\
\hline $\begin{array}{l}\text { Market value } \\
\text { (Var.Eksogen) }\end{array}$ & $\begin{array}{l}\text { Harga saham yang terjadi di bursa } \\
\text { pada saat tertentu yang ditentukan } \\
\text { oleh pelaku pasar (Jogiyanto } \\
\text { Hartono, 2003: 88) }\end{array}$ & $\begin{array}{l}\text { Mengalikan rata-rata harga } \\
\text { pentupan saham harian dalam satu } \\
\text { tahun dengan jumlah saham beredar } \\
\text { pada tahun yang sama (Persamaan } \\
\text { 2) }\end{array}$ & Rasio \\
\hline $\begin{array}{l}\text { Variance of } \\
\text { stock return } \\
\text { (Var. Eksogen) }\end{array}$ & $\begin{array}{l}\text { Pengukuran besarnya risiko total } \\
\text { yang dikaitkan dengan expected } \\
\text { return dari suatu investasi (Atkins } \\
\text { and Dyl, 1997: 132) }\end{array}$ & $\begin{array}{l}\text { 1. Menghitung return harian } \\
\text { (HPY }{ }_{\text {iT }} \text { dengan cara membagi } \\
\text { selisih harga penutupan saham } \\
\text { pada t dan harga penutupan } \\
\text { saham pada t-1 dalam tahun } \mathrm{T} \\
\text { dengan harga penutupan saham } \\
\text { pada t-1 dalam tahun } \mathrm{T} \text {. } \\
\text { 2. Menghitung rata-rata return } \\
\text { harga harian (E(HPY }(\mathrm{HP}) \text { ) dengan } \\
\text { cara membagi penjumlahan } \\
\text { HPY } \text { iT dengan total jumlah hari } \\
\text { perdagangan dalam tahun T. } \\
\text { 3. Menghitung varian dari return } \\
\text { harian dalam satu tahun, } \\
\text { dengangunakan Persamaan (3), } \\
\text { (4) dan (5). }\end{array}$ & Rasio \\
\hline
\end{tabular}




\section{Analisis Data}

Alat analisis yang akan digunakan untuk mengestimasi persamaan dalam model penelitian tersebut adalah alat analisis 2 SLS (Two Stage Least Square) yang dikembangkan oleh Henri Theil dan Robert Basmann (Gujarati, 1995: 686-690), yaitu metode perhitungan kuadrat terkecil dua tahap secara berturut-turut.

\section{Tahap 1 (First Stage)}

$\mathrm{SPD}_{\mathrm{T}}=\alpha_{1}+\beta_{1}$ SPD $_{\mathrm{T}-1}+\beta_{2} \mathrm{MV}_{\mathrm{T}}+\beta_{3}$ $\mathrm{VAR}_{\mathrm{T}}+\varepsilon_{1}$

Selanjutnya bid-ask spread hasil estimasi dari regresi linier berganda tahap pertama dijadikan variabel bebas untuk mengestimasi variabel tergantung holding period dengan menggunakan regresi linier berganda tahap kedua.

\section{Tahap 2 (Second Stage)}

$\mathrm{HP}_{\mathrm{T}}=\alpha_{2}+\beta_{4} \hat{S} P D_{T}+\beta_{5} \mathrm{MV}_{\mathrm{T}}+\beta_{6}$

$\mathrm{VAR}_{\mathrm{T}}+\varepsilon_{2}$

Keterangan :

$\mathrm{SPD}_{\mathrm{T}-1}$ : persentase rata-rata bid-ask spread untuk saham badan usaha i di BEJ dalam tahun $\mathrm{T}-1$ pada periode 2002-2004

$\mathrm{SPD}_{\mathrm{T}}$ : estimasi dari persentase rata-rata bid-ask spread untuk saham badan usaha I di BEJ dalam tahun $\mathrm{T}$ pada periode 2002-2004

$\mathrm{HP}_{\mathrm{T}}$ : lama waktu rata-rata investor memegang saham badan usaha I di BEJ dalam tahun $\mathrm{T}$ selama periode 2002-2004

$\mathrm{MV}_{\mathrm{T}}$ : market value rata-rata saham badan usaha I di BEJ dalam tahun $\mathrm{T}$ selama periode 2002-2004

$\mathrm{VAR}_{\mathrm{T}}$ : variance of stock return saham badan usaha I di BEJ dalam tahun T selama periode 2002-2004

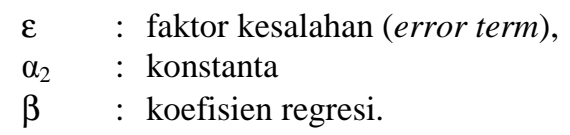

Tujuan uji tahap pertama ini hanya untuk mendapatkan nilai prediksi dari variabel $\operatorname{SPD}_{\mathrm{T}}\left(\hat{S} P D_{T}\right)$ yang dipengaruhi oleh SPD ${ }_{\mathrm{T}-1}$. Jadi model tahap pertama bukan masalah penelitian, sehingga tidak dirumuskan hipotesis penelitiannya.

\section{Pengujian Hipotesis \\ Uji BLUE (Best Linier Unbiased Estimators) \\ Uji asumsi klasik yang digunakan pada penelitian ini meliputi uji multikolinearitas, otokorelasi, heteroskedas- tisitas, dan normalitas. Uji ini dilakukan baik pada model tahp pertama maupun kedua.}

\section{Uji hipotesis statistik}

Uji statistik dilakukan hanya untuk model tahap kedua saja. Model tahap pertama hanya untuk mendapatkan nilai spread prediksi $\left(\hat{S} P D_{T}\right)$. Untuk hubungan partial dilakukan uji t, dan untuk hubungan simultan dilakukan uji F.

\section{Uji koefisien determinasi (R2)}

Nilai $R^{2}$ (koefisien determinasi) digunakan untuk mengetahui besarnya kontribusi (pengaruh) yang diberikan oleh variabel independen $\left(\mathrm{X}_{\mathrm{i}}\right)$ dalam terhadap variabel dependen $(\mathrm{Y})$ pada model tahap kedua.

\section{HASIL ANALISIS DAN PEMBAHASAN Statistik Deskriptif}

Hasil analisis deskripsi variabel penelitian disajikan pada Tabel 4. 
Jurnal Siasat Bisnis Vol. 12 No. 3, Desember 2008 Hal: 161-173

Tabel 4: Statistik Deskriptif Variabel Penelitian

\begin{tabular}{lcccccc}
\hline \multicolumn{1}{c}{ Keterangan } & Min & Max & Mean & Median & Std Deviation & $\mathrm{n}$ \\
\hline Market Value & 19,63 & 29,42 & 25,54 & 25,85322439 & 1,96 & 90 \\
Variance & $-13,1770$ & $-2,8626$ & $-6,2189$ & $-6,349060186$ & 1,8369 & 90 \\
Spread & $-5,2014$ & $-0,4888$ & $-2,4268$ & 2,2131 & 0,9293 & 90 \\
Holding period & $-3,95$ & 6,52 & 2,42 & $-2,390031758$ & 2,19 & 90 \\
\hline
\end{tabular}

Sumber : Hasil pengolahan data SPSS ( lampiran 2)

\section{Uji Hipotesis Statistik}

Uji asumsi klasik, baik untuk model tahap pertama maupun kedua, memenuhi asumsi klasik (hasil pada Lampiran 3). Jadi model ini memenuhi syarat sebagai model penelitian.

Uji hipotesis statistik dilakukan hanya untuk model kedua saja, Model pertama hanya untuk memperoleh nilai variabel spread prediksi $\left(\hat{S} P D_{\mathrm{T}}\right)$. Nilai bidask spread ramalan diperoleh dari hasil perhitungan tahap pertama, yang dijadikan dasar untuk perhitungan OLS tahap kedua. Hasil perhitungannya dapat dilihat pada Lampiran 4. Hasil perhitungan model kedua dalam bentuk persamaan diperoleh persamaan statistik sebagai berikut:

$$
\begin{aligned}
\mathrm{HP}= & -17.452+1.493 \hat{S} P D_{\mathrm{T}} \\
\mathrm{T} \text { sig } & \multicolumn{2}{c}{0,0009} \\
& +0.825 \mathrm{MV}_{\mathrm{T}}-0.396 \mathrm{VAR}_{\mathrm{T}} \\
& 0,0001 \quad 0,0018 \\
\mathrm{~F} \mathrm{sig} & =0,0000 \\
\mathrm{R}^{2} & =0.31443
\end{aligned}
$$

Dari persamaan statistik model kedua diketahui bahwa semua variabel penelitian memiliki arah yang benar (konsisten) sebagaimana hipotesis yang diajukan dan signifikan. pada bagian ini dilakukan uji-F dan uji-t untuk membahas model holding period yaitu pengaruh prediksi bid-ask spread, market value, dan variance of stock return terhadap holding period, dapat dikemukakan sebagaimana sebagai berikut :

\section{Pengaruh prediksi bid-ask spread ( $\hat{S} P D$ ) terhadap holding period (HP)}

Bid-ask spread sebagai proksi variabel transaction cost merupakan perbedaan antara harga order jual terendah dengan harga order beli tertinggi. Dari hasil analisis diketahui bahwa secara individu variabel bid-ask spread (SPD) memiliki arah pengaruh yang positif terhadap holding period (HP). Hal ini menunjukkan bahwa makin tinggi bid-ask spread, makin lama holding period, sebaliknya makin rendah bid-ask spread, makin singkat holding period. Hal ini dapat dipahami karena dalam melakukan investasi di pasar modal. investor memperhatikan besarnya transaction cost yaitu bid-ask spread. Dalam melakukan transaksi jual dan beli saham, investor harus menentukan batas harga order jual saham terendah (ask price) dan batas harga order beli saham tertinggi (bid price) yang diinginkannya. Makin tinggi bid price, makin besar pengeluaran yang dilakukan investor untuk memperoleh saham yang diinginkan, yang menyebabkan makin tinggi pula ask price yang ditentukan investor untuk melepas saham yang dipegangnya agar investor tersebut mendapatkan return yang diinginkannya. Hal ini menyebabkan bid-ask spread makin lebar. Investor cenderung menahan saham yang dipegangnya apabila ask price yang ditentukannya belum tercapai, sehingga holding periodnya makin lama. Berdasarkan temuan empiris ini. maka penelitian ini masih konsisten dengan hasil penelitian Atkins dan Dyl (1997); Vinus Maulina (2003) yang 
menyatakan bahwa bid-ask spread berpengaruh positif terhadap holding period.

Penelitian Lenny dan Indriantoro (1999), menemukan hubungan yang tidak signifikan. Hal ini karena di Indonesia pada periode 1995-1996 sedang mengalami pertumbuhan yang cepat. Sehingga dalam melakukan investasi, orang tidak terlalu memperhatikan adanya biaya transaksi melainkan hanya memperhatikan perubahan harganya saja. Demikian pula hasil penelitian dengan penelitian Yenny (2003) dan Puspitasari (2005) memberikan hasil tidak signifikan, karena objek penelitian mereka hanya berupa saham-saham teraktif. Saham-saham teraktif tersebut memiliki jumlah taransaksi yang besar sehingga investor tidak memperhatikan biaya transaksi melainkan dari perubahan harga saja, yang menyebabkan bid-ask spread mempunyai arah yang negatif terhadap holding period.

\section{Pengaruh market value (MV) terhadap holding period (HP)}

Hasil analisis diketahui bahwa secara individu variabel market value (MV) memiliki arah pengaruh yang positif terhadap holding period (HP). Nilai ini menunjukkan bahwa market value memberikan arah pengaruh yang positif (searah) terhadap holding period. Hal ini berarti bahwa makin besar market value. akan menyebabkan holding period makin lama.

Dengan demikian, makin tinggi market value menunjukkan makin besarnya skala badan usaha. Badan usaha besar cenderung mempunyai earning yang lebih stabil sehingga dapat menjanjikan distribusi return yang lebih stabil daripada badan usaha kecil. Investor cenderung menahan saham yang mempunyai market value yang lebih tinggi, sehingga holding period-nya makin lama. Hasil temuan ini konsisten dengan hasil penelitian Atkins dan Dyl
(1997); Miapuspita, dkk (2003); Puspitasari (2005). Jadi hipotesis ini dapat dibuktikan.

\section{Pengaruh variance of stock return (VAR) terhadap holding period}

Hasil analisis dapat diketahui bahwa secara individu variabel variance of stock return (VAR) memiliki arah pengaruh yang negatif terhadap holding period (HP). Hal ini berarti bahwa makin besar variance of stock return. akan menyebabkan holding period makin singkat, sebaliknya makin rendah variance of stock return makin lama holding period. Hal ini dapat dipahami karena variance of stock return merupakan pengukuran langsung dari volatilitas saham badan usaha. Makin volatil saham badan usaha menunjukkan resiko yang diterima investor makin tinggi. Investor cenderung memilih resiko serendah mungkin. Apabila suatu saham usaha mempunyai resiko tinggi cenderung dilepas oleh investor tersebut. sehingga holding period makin singkat. Hasil temuan ini masih konsisten dengan hasil penelitian Atkins dan Dyl (1997), dan hipotesis yang menyatakan bahwa variance of stock return berpengaruh negatif terhadap holding period dapat dibuktikan.

Penelitian Miapuspita, Iramani dan Purnamasari (2003), yang menyatakan variance of stock return tidak berpengaruh signifikan terhadap holding period. Hal tersebut dapat terjadi karena pada periode 2001-2002 investor menginvestasikan dananya, tidak sekedar untuk mencari keuntungan dari perubahan harga saja, tetapi investor juga memiliki tujuan untuk membangun perusahaannya. Penelitian ini juga tidak konsisten dengan hasil penelitian Puspitasari (2005) karena objek penelitiannya berupa saham LQ45 sehingga tidak mewakili keseluruhan saham-saham yang ada. 
Pengaruh prediksi Bid-Ask Sprea, Market Value, dan Variance of Stock Return Secara Simultan Terhadap Holding period

Berdasarkan hasil analisis diketahui bahwa terdapat pengaruh bid-ssk spread, market value, dan variance of stock return secara simultan berpengaruh signifikan terhadap holding period. Hasil ini memperkuat hasil penelitian yang dilakukan oleh Atkins dan Dyl (1997), Lenny dan Indrianto (1999), Subali dan Zuhroh (2002), Yenny Ayu. Miapuspita. Iramani dan Purnamasari (2003), Puspitasari (2005). Tapi penelitian ini tidak konsisten dengan penelitian Maulina (2003) yang menyatakan bahwa bid-ask spread, market value, variance of stock return secara bersama-sama tidak mempunyai pengaruh terhadap holding period. Hal ini dikarenakan pada periode 2000-2001 Indonesia masih mengalami krisis ekonomi sehinnga jumlah investornya sedikit. Maka bid-ask spread, market value, dan variance of stock return secara simultan tidak berpengaruh terhadap holding period.

\section{PENUTUP}

Berdasarkan hasil penelitian yang telah dilakukan dengan melalui tahap pengumpulan dan pengolahan data, analisis dan interpretasi hasil analisis mengenai hubungan antara variabel bebas dan variabel terikat, maka dapat ditarik beberapa kesimpulan sebagai berikut: 1). Bid-ask spread berpengaruh positif terhadap holding period; 2). Market value berpengaruh positif terhadap holding period; 3). Variance of stock return berpengaruh negatif terhadap holding period; 4). Bid-ask spread, market value, variance of stock return secara bersama-sama mempunyai pengaruh secara signifikan terhadap holding period.

Beberapa keterbatasan penelitian ini meliputi: 1). Penelitian ini hanya membahas tiga variabel saja yang mempengaharui holding period. Ada variabel lain yang mempengaharui holding period. Salah satu diantaranya adalah dividend payout ratio. 2). Adanya keterbatasan waktu dan dana dalam membahas lebih mendalam mengenai semua variabel yaitu bid-ask spread, market value, dan variance of stock return.

Berdasarkan hasil penelitian yang telah dikemukakan maka dapat diberikan beberapa saran, antara lain sebagai berikut:

a. Bagi investor

Dari hasil penelitian ini maka disarankan kepada investor, bahwa dalam mengambil keputusan mengenai holding period saham biasa di Bursa Efek Jakarta hendaknya melihat baik faktor internal (misalnya bid-ask spread, market value, dan variance of stock) maupun eksternal perusahaan (misalnya kondisi makro ekonomi).

b. Bagi peneliti selanjutnya

Dari hasil penelitian yang telah dilakukan dan menghasilkan kesimpulan bahwa variabel bebas yang dimasukkan dalam model hanya mampu menjelaskan pengaruhnya terhadap variabel terikat (holding period) sebesar $31.44 \%$ saja, sedangkan sisanya sebesar $68.56 \%$ dipengaruhi oleh variabel lain yang tidak dimasukkan dalam model persamaan regresi yang diuji, maka untuk penelitian selanjutnya hendaknya ditambahkan variabel bebas lainnya yang memiliki pengaruh terhadap holding period.

\section{DAFTAR PUSTAKA}

Halim, A, dan Hidayat, N. (2000). Studi Empiris Tentang Pengaruh Perdagangan Return Terhadap Bid-ask Spread Saham Industri Rokok di BEJ dengan Metode Koreksi Kesalahan. Jurnal Riset Akuntansi Indonesia, 3 (1), 69-85.

Alfons dan Ernawati, E. (2005). Pengaruh Transaction Cost, Market Value, dan Variance of Stock Return 
Terhadap Holding Period pada Saham-Saham di Bursa Efek Jakarta Periode 2000-2001. The $4^{\text {th }}$ Ubaya International Symposium on Management, 212-228.

Atkins, A.B. and Dyl, E.A. (1997). Transactions Costs and Holding Periods for Common Stocks. The Journal of Finance, 52 (1), 309-325.

Brigham, E.F. and Houston, J.F. (2001). Fundamentals of Financial Management. $9^{\text {th }}$ edition. Orlando: Harcourt College Publisher.

Brockman, P. and Chung, D.Y. (1999). BidAsk Spread Components in An Order-Driven Environment. The Journal of Financial Reseach, 22 (2), 227-246.

Darmadji, Tj dan Fakhruddin, H.M. (2001), Pasar Modal di Indonesia: Pendekatan Tanya Jawab. Jakarta: Salemba Empat.

Demzets, H. (1968). The Cost of transacting. Quaterly Journal of Economic, 82, 33-53.

Downes, J. and Goodman, J.E. (1999). Kamus Istilah Keuangan dan Investasi. Jakarta: PT. Elex Media Komputindo.

Fatmawati, S. dan Asri, M. (1999). Pengaruh Stock Split terhadap Likuiditas Saham yang Diukur dengan Besarnya Bid-Ask Spread di Bursa Efek Jakarta. Jurnal Ekonomi dan Bisnis Indonesia, 4, 93-110.

Hartono, J. (2003). Teori Portofolio dan Analisis Investasi. Edisi Ketiga. Yogyakarta: Penerbit BPFE.

Husnan, S. (1998). Dasar-dasar Teori Portofolio dan Analisis Sekuritas. Yogyakarta: UPP AMP YKPN.
Jones, C.P. (2002). Investment: Analysis and Management. $7^{\text {th }}$ edition. New York: John Wiley and Sons, Inc.

Leny dan Indriantoro, N. (1999). Analisis Pengaruh Transaction Cost Terhadap Lamanya Holding Period Saham Biasa. Jurnal Bisnis dan Akuntansi, 1 (3), 209-220.

Miapuspita, Y.A. Iramani, dan Purnamasari, P. (2003). Analisis Pengaruh BidAsk Spread, Market Value, dan Risk of Return Saham terhadap Holding Period Pada Saham Teraktif Yang Tercatat di BEJ periode 2001-2002. Ventura, 6 (2), 117-125.

Nazir, M. (1999). Metode Penelitian. Edisi ke-3. Ghalia Indonesia.

Santoso, S. (2000). Mengatasi Berbagai Masalah Statistik dengan SPSS versi 11.5. Jakarta: PT Elex Media Komputindo.

Sharpe, W.F., Gordon J.A. and Jeffrey V.B. (1999). Investments. New Jersey: Prentice Hall.

Subali dan Zuhroh, D. (2002). Analisis Pengaruh Transaction Cost Terhadap Holding Period Saham Biasa. Jurnal Riset Akuntansi, 5 (2), 193-213.

Sunariyah. (1997). Pengantar Pengetahuan Pasar Modal. Edisi Ketiga. Yogyakarta: UPP AMP YKPN.

Van Horne, Wachowicz, JR, and John M. (1998). Prinsip-prinsip Manajemen Keuangan. Jakarta: Salemba Empat.

Widoatmodjo, S. (1996). Cara Sehat Investasi di Pasar Modal. Jakarta: Yayasan Mpu Ajar Artha. 